\title{
Die teken van Jona en Jesus as Messias
}

FE Deist

Opgedra aan die nagedagtenis van my vriend en oud-kollega, Willem Vorster, wat in sy lewe ' $n$ besondere belangstelling gehad het vir die Sinoptiese Evangelies en die Joodse agtergrond van die Nuwe Testament.

\section{ABSTRACT}

The sign of Jonah and Jesus as Messiah

Jewish tradition and the contexts in which Matthew and Luke refer to the "sign of Jonah" suggest that the sign demanded of Jesus by the authorities should prove his prophetic authority for deviating from traditional Torah. In the light of Jewish tradition on Jonah ben Amittci as the (Ephraimite) Messiah ben Joseph the mention of the sign itself may' suggest that, at least in Matthew, Jesus claims messianic authority, and implies his eschatological victory over all evil powers, leading to the messianic banquet of believers.

Daar sou ' $n$ boek geskryf kon word oor die verklarings vir die "teken van Jona" waarna daar in Matteus 12:39-41 (Luk 11:29-32) verwys word. Die sienings oor die implikasies van die verwysing verskil reeds in die evangelies. Volgens Lukas is dit aan die "balhorige" skare gerig, omdat hulle 'n teken (by Jesus?) gesoek het, maar volgens Matteus kom die verwysing na Jona in die konteks van 'n strydgesprek van Jesus met die Fariseèrs. By Lukas het die teken te make met 'n vergelyking tussen die heidene van Ninevé wat hulle op die prediking van 'n profeet bekeer het, terwyl die Joodse tydgenote van Jesus nie na sy prediking wou luister nie. By Matteus gaan die teken 6́6k oor 'n vergelyking met die mense van Ninevé, maar daar is 'n plus: soos Jona drie dae en drie nagte in die vis was, so sal die Seun van die mens drie dae en drie nagte in die graf wees.

In die moderne uitleg van die Sinoptiese Evangelies is daar, aan die een kant, diegene wat die verwysing na Jona as 'n outentieke Jesuswoord opneem en aanvaar dat Jesus na die profeet Jona, die hoofkarakter in die boek Jona, verwys. Die argument sentreer dan hoofsaaklik om die vraag of Jesus letterlik drie dae en drie nagte in die graf was en hoe dié uitdrukking verstaan moet word ${ }^{1}$. Aan die ander kant is daar diegene wat meen dat die verwysing heeltemal niks met die profeet Jona of die gelyknamige boek te make het nie, maar wel met die Jona-figuur in die Vitae prophetarum, waarvolgens Jona 'n teken aangaande Jerusalem aangekondig het: "As julle 'n klip in die muur sien wat uitroep, is die einde naby; en as julle allerlei volkere in Jerusalem gewaar, word die stad tot op sy fondamente verwoes"2. So verstaan, is die "teken" van Jona eintlik 'n blote eskatologiese vooruitskou. Daar is ook meer "neutrale" uitleggers wat reken dat Matteus die "uitvinder" van die ietwat geforseerde vergelyking met Jona was en dat hy dit bloot gebruik vir die effek van die parallel ${ }^{3}$.

In die lig van die lang geskiedenis van uitleg van die betrokke tekste deur kompetente eksegete sou dit arrogant wees om te wil voorgee dat "die" antwoord nou uiteindelik beskikbaar is. Daar het egter in 1992 'n belangrike proefskrif by die Universiteit van Stellenbosch (Departement Ou Nabye Oosterse Studie) verskyn wat moontlik nuwe lig op die Nuwe-Testamentiese verwysings na Jona kan werp. 
Rabbi Arthur Seltzer het in sy omvangryke proefskrif, Esoteric themes in the book of $J o n a h^{4}$, 'n groot aantal eksoteriese en esoteriese Joodse interpretasies van die boek Jona versamel. Hoewel dit in die proefskrif bloot oor die geskiedenis van die Joodse interpretasie handel, kan sommige dele van veral die esoteriese (of allegoriese) Joodse interpretasies van die Jonaboek nuwe insig bring in die messiaanse konteks waarin die Nuwe Testament, en dan veral Matteus, die verwysing na Jona plaas.

\section{DIE NUWE-TESTAMENTIESE KONTEKS WAARIN NA JONA VERWYS WORD}

Die debat oor of Matteus en Lukas se Jonaverwysings "egte" Jesuswoorde is en of dié uitspraak iets kan sê oor die historisiteit van Jona al dan nie, het uiteindelik met die betekenis van die Jonaverwysings in die Sinoptiese Evangelies niks te make nie. Die betekenis van die Jonaverwysings in Matteus en Lukas moet uit die tekste self en uit kennis wat die evangeliste by hulle gehoor kon veronderstel, afgelei word. As Schmitt dus in Joodse geskrifte gaan soek vir 'n interpretasie van Jona se lewe wat lig kan werp op die Jonaverwysing in die Nuwe Testament, is hy op 'n beter pad as die meer "konserwatiewe" uitleg van die perikope.

Die probleem met Schmitt se interpretasie 5 is egter dat hy, om sy verklaring aanvaarbaar te maak, eers die Jonaverwysing moet reduseer tot die "egte" Jesuswoord (wat dan bloot sou verwys na die "teken van Jona") en die redaksionele verklaring van die teken ${ }^{6}$ as 'n soort misverstand by die evangeliste moet klassifiseer. Selfs as dié redaksie-historiese analise korrek is, kan dit nog nie verklaar waarom die evangeliste dan 'n ander betekenis aan die "teken" geheg het of wat die redaksionele interpretasie self presies beteken nie. Die "teken van Jona" in die Vitae prophetarum het 'n eskatologiese konteks (Jerusalem word verwoes), wat vreemd is aan die kontekste waarin die Nuwe-Testamentiese Jonaverwysings voorkom. As die verwysings dus in die sogenaamde "profetiese redes" verskyn het, sou Schmitt se verklaring waarskynliker wees. Dit is egter nie die geval nie. Ten slotte is dit baie duidelik dat die verwysings na Jona in sowel Matteus as Lukas inderdaad by die boek Jona aansluit, eerder as by die Vitae Prophetarum. Die oplossing van die vraag na die betekenis van die Jonateken moet dus eerder in die konteks van die Evangelies self en in die resepsiegeskiedenis van die boek Jona gesoek word.

In die Lukas- en Matteusevangelies volg die verwysing na Jona telkens direk ná 'n dispuut met die Joodse geestelike gesagsdraers. Hoewel Lukas 11 die genesing van die besetene nie eksplisiet op 'n sabbat laat plaasvind nie, is dit wel die geval in Matteus. In Matteus 12 gaan die dispuut oor die oortreding van die Tora toe Jesus se volgelinge honger geword het en op die sabbat are uitgevryf het, en Jesus 'n man op die sabbat genees het. Die soeke na 'n teken (sy dit deur die skare of die Joodse geestelikes) moet dus in daardie konteks verstaan word: die mense soek 'n teken by Jesus om sy outoriteit te bewys.

Rabbi Abraham ben Esra het in dié verband in die naam van Rabbi Jesaja gesê7:

tekens en wonders word nie van 'n profeet gevra as hy mense leer en vermaan om die Tora te onderhou nie..., maar as hy mense as gevolg van die nood van die omstandighede in die Naam van God opdrag gee om 'n verordening uit die 
gebooie van die Tora te oortree - behalwe natuurlik om afgodery te bedryf - dan is dit gepas dat hy'n wonder doen om sy profesie te bevestig.

Sowel in die geval waar die dissipels are uitvryf as waar die besetene genees word, gaan dit om 'n noodgeval. In die beide gevalle verwys Matteus direk na ander noodgevalle waartydens die Tora oortree sou kon word of oortree is (Matt 12:3-5, 11-12). Jesus se "oortreding" van die Wet kan egter nie met die blote verwysing na presedente bygelê word nie. Daarom wil die mense, en dan veral die Wetskenners, 'n teken sien wat Jesus se profetiese gesag sou demonstreer - veral nadat Hy die Wetskenners vir ' $n$ "addergeslag" uitgemaak het en daarmee húlle gesag uitgedaag het (Matt 12:34).

In die konteks van die doelstellings van die evangeliste self gaan dit egter kennelik om meer as net 'n bewys van Jesus se profeetstatus. By hulle - veral dan by Matteus - gaan dit oor die bewys van Jesus se messiaanse gesag. Vandaar die verwysings by Matteus na die Seun van die mens $(12: 8,32)$ en by Lukas na die vrou wat Jesus "geseënd" genoem het (11:27). Dit is dan binne dié konteks dat Jesus sê dat Hy vir hulle die teken van Jona gee. Die vraag is wat die gehoor, wat telkens hierna stilbly, veronderstel was om onder die "Jonateken" te verstaan en wat die (Joodse) lesers van die Matteusevangelie onder dié kriptiese verwysing sou begryp.

Die verwysing na die Nineviete wat in die oordeelsdag teen Jesus se tydgenote sal getuig, omdat hulle hulle opreg bekeer het, is duidelik ${ }^{8}$. Die Matteusevangelie verbind egter die interpretasie van die teken ook nog aan Jona se drie daelange verblyf in die vis en met Jesus se verblyf in die graf. Dit is juis in dié verband dat die Joodse literatuur'n interessante perspektief op die "teken van Jona" kan bied.

Jona ben Amittai, so heet dit in die Joodse tradisie", was inderwaarheid die seun van die weduwee van Sarfat wat deur Elia uit die dood opgewek is en so 'n tweede lewe ontvang het ${ }^{10}$. Met sy vlugtog na Tarsis beland hy vir die tweede keer in lewensgevaar toe die matrose hom op sy versoek oorboord gooi en hy in die maag van 'n vis beland. In die Joodse eksegese gaan dit in die Jonaverhaal nie bloot oor 'n toevallige ongehoorsame profeet nie, maar our gebeure wat al sedert die skepping beskik is. Die groot vis wat hom uiteindelik insluk, is reeds op die sesde skeppingsdag geskape met die uitsluitlike doel om Jona uit die see op te pik ${ }^{11}$.

Oor Jona se verblyf in die vis lui dit in die Joodse tradisie ${ }^{12}$ :

Dit is bekend dat dit nie moontlik is dat 'n mens selfs vir' $n$ uur in die maag van 'n vis kan oorleef nie, want 'n mens moet uit die buitelug koel lug inasem. Aangesien die dood(svonnis) reeds oor hom uitgespreek was, en hy homself 
daarom beskou het asof vir 'n tweede keer gebore, het God hom die status van 'n fetus gegee, wat na bevrugting vir nege maande in sy moeder se uterus bewaar word sonder om asem te haal.

In hierdie interpetasie (rasionalisasie?) dat Jona wel in die vis gesterf het en weer lewend gemaak is, lê die kiem van die Joodse tradisie oor Jona as die Efraimitiese Messias. In dié verband sê Ashlikh13: "Die punt is dat Jona die Messias ben Josef is, want hy is die seun van die weduwee van Sarfat."

Jona se messiaanse sending sou egter nie sonder lyding volbring kon word nie. As gevolg van sy verblyf in die ingewande van die vis, so gee Ibn Esra die Joodse tradisie weer, het Jona se vel teer geword, sodat die son hom, toe hy weer buite kom, verskriklik gebrand het. En in die Midrash Jona lui dit: "En van die geweldige hitte in die vis is Jona se klere en hare geskroei, en vlieë, muggies, wurms en vlooie het oor hom geswerm". Dié tema is later in die tradisie uitgebrei dat Jona inderdaad in die vuur van Gehenna self gebrand het ${ }^{14}$.

Sy verblyf in die vis was egter nie net bedoel vir sy louteringsproses as Messias nie. Dit is ook so beskik met die doel dat hy na die dieptes van die oseaan kon afdaal om die Leviatan te sien wat hy aan die einde van sy lewe moes verslaan. In die Joodse tradisie is die Leviatan, wat in die Ou Nabye Oosterse mitologie een van die chaosmonsters was, mettertyd met Satan, of die engel van die verwoesting, verbind. Die Messias ben Josef sou aan die einde van die tyd hierdie slang doodmaak en sy liggaam opsny en sy vleis voorberei vir die eskatologiese oorwinningsmaal ${ }^{15}$. In Friedlander se vertaling van Pirke de-Rabbi Eliezer ${ }^{16}$ sê Jona onder meer aan die Leviatan:

On thy account have I descended to see thy abode in the sea, for, moreover, in future will I descend and put a rope in they tongue, and I will bring thee up and prepare thee for the great feast of the righteous. (Jonah) showed it the seal of our father Abraham (saying), Look at the Covenant (seal), and Leviathan saw it and fled before Jonah a distance of two day's journey...

Daar in die vis (simbool van die sterwe van Jona) maak Jona dan teenoor God die gelofte dat hy bereid is om die Leviatan aan te val en te verslaan om Israel so vir ewig te verlos. Dit is wanneer Jona dié gelofte maak, dat God die vis opdrag gee om Jona op droë grond uit te spuug.

Dit is in dié verband miskien nie toevallig dat sowel Lukas as Matteus die verwysing na die teken van Jona, naas in die konteks van die outoriteitsvraag, ook in die konteks van die uitdryf van duiwels plaas en na Beëlsebul, die owerste van die duiwels, verwys nie (Matt 12:24; Luk 11:15). Jona was in die Joodse tradisie intens gemoeid met die uitwissing van Leviatan (die bose) en die gevolglike verlossing van Israel. Die Joodse leiers verbind Jesus se mag oor die duiwels egter nie met sy messiaanse gesag nie en beskou sy mag juis as duiwelse mag ${ }^{17}$. Wanneer Matteus dan in dié konteks na die teken van Jona verwys - en pertinent na Jona se verblyf in die 
vis - is die suggestie sterk dat hy daarmee juis Jesus se messiaanse sending en gesag (oor die bose) wil beklemtoon.

Hoewel die verwysing na Jona nie in enige van die evangelies in 'n eskatologiese konteks staan nie, is daar tog in die suggestie van Jesus se dood (Matt 12:40) 'n implisiete eskatologiese verwysing, wat versterk word deur die Joodse tradisie oor die toekoms van Jona as die Messias ben Josef. Oor wanneer Jona sal terugkeer om die Leviatan finaal te verslaan, is in die Joodse tradisie nie seker nie. Volgens die messiaans tekste wat Patai 18 versamel het, vra Moses vir God wanneer die Nuwe Jerusalem gebou sal word, en God antwoord: "Ek het die tyd aan niemand bekend gemaak nie, nie aan die eerstes nie en ook nie aan die laastes nie. Hoe kan Ek dit vir jou vertel?". Maar as Moses dan aandring op 'n teken van die eindtyd, antwoord God: "Ek sal die kinders van Israel eers met die wanvurk verstrooi... na die vier hoeke van die aarde. Dan sal Ek my hand 'n tweede keer uitsteek en hulle wat saam met Jona ben Amittai na Bo-Egipte gegaan het, versamel, en dié in Hamat en in Elam en in Etiopië".

In dié eskatologiese tradisie, so toon Seltzer ${ }^{19}$ aan, begin die vereenselwiging van die Messias ben Josef (wat aanvanklik bloot ' $n$ wegbereider was) met die Messias ben Dawid (wat tradisioneel die eintlike Messias was). In sommige Joodse kringe is die Messias ben Dawid die terugkerende Messias ben Josef, ofte wel die herrese Jona ben Amittai.

Die Messias ben Josef (Jona ben Amittai) is - soos Elia, wat hom die eerste keer uit die dood opgewek het - lewend opgeneem in die hemel en wag nou die tyd ( 990 jaar) ${ }^{20}$ af vir sy finale koms om die Leviatan te verslaan ${ }^{21}$. Hierna neem God hom in die hemel op en beklee hom met sy eie heerlikheid. Dan sit al die verlostes vir tweeduisend jaar lank saam met die Messias aan om die fees van die voleinding te vier en die vleis van die Leviatan te eet wat die Messias vir hulle voorberei het ${ }^{22}$.

\section{GEVOLGTREKKING}

Hoewel dit uiters moeilik is om die Joodse tradisies oor Jona te dateer, omdat dit nie seker is wanneer die tradisies wat later opgeteken is, presies ontstaan het nie, en 'n mens daarom verkeerdelik latere interpretasies kan gebruik om die (vroeëre) Nuwe-Testamentiese tekste te verstaan, kan Joodse tradisies tog op drie vlakke interessante lig werp op Matteus 11, en dan veral op die verwysing na Jona se verblyf in die vis.

In die eerste plek kan die Joodse tradisie, as dit as gehoorkennis by die 
literêre konteks van Matteus 11 veronderstel word, 'n aanduiding wees dat die versoek aan Jesus om 'n teken te doen, 'n versoek was om sy profetiese gesag om (in noodsituasies) van die Tora af te wyk, te bevestig.

Tweedens kan die verwysing na Jona in die vis ' $n$ implisiete messiaanse aanspraak wees - wat bes moontlik deur die gehoor gesnap sou word. Soos Jona gedurende die drie dae wat hy in die vis was, sy finale opdrag as uitwisser van die bose en verlosser van Israel plegtig aanvaar het ${ }^{23}$ en toe weer lewend uitgespuug is om sy taak te volvoer, so sou dit ook met Jesus van Nasaret gebeur. Hy is dus vir Matteus die verwagte Messias wat "Leviatan" sal vernietig en nie die owerste van die duiwels, soos die geestelikes beweer het, nie. Dat Hy drie dae "in die hart van die aarde" sal wees (Matt 11:40) impliseer dan eintlik die res van die tradisie oor Jona as Messias.

Laastens kan die Joodse tradisie ook lig werp op die eskatologiese interpretasie wat die Nuwe Testament aan die sterwe en opstanding van Jesus gee. As die Messias sal Hy die bose finaal oorwin en saam met die verlostes aan die eskatologiese maaltyd aansit om die ondergang van die bose en die aanbreek van die Messiaanse ryk te vier.

\section{NOTAS:}

1 Vergelyk F W Grosheide, Het heilige Evangelie volgens Mattheus (CNT), Amsterdam 1922, 157.

2 G Schmitt, "Das Zeichen des Jona", Zeitschrift für die neutestamentliche Wissenschaft 69 (1978), 123-129.

3 Vergelyk C Allen, $A$ critical and exegetical commentary on the Gospel according to S. Matthew, Edinburgh 1947, 139: "Mt. turned to the Book of Jonah, and found in $2^{1}$ the words: [and Jonah was in the belly of the fish three days and three nights]. Here was material for a comparison. Jonah's wonderful experience of guidance and salvation culminated in his sojourn in the belly of the sea monster followed by his miraculous deliverance. This ... made him a sign to the Ninevites". Die Nineviete sou egter nie weet dat Jona deur ' $n$ vis ingesluk en uitgespuug is nie, sodat sy ervarings kwalik vir húlle 'n teken kon wees.

$4 \quad$ Onder promotorskap van J Cook.

5 Hiermee wil ek graag 'n korreksie aanbring aan my vroeëre aanvaarding van dié opvatting. Kyk F E Deist, Die God van Jona, Kaapstad 1981, 6-7.

6 So ook W F Albright \& C S Mann, Matthew. Introduction, translation and notes (Anchor Bible 26) New York 1971, 159. 

proefskrif, US), Stellenbosch 1992, 124.

8 Ook in die Joodse interpretasie van die Jonaboek staan die bekering van die Nineviete vir egte en ware bekering. In die Mishnatraktaat Taanit 2:1 lui dit: "Broers, daar staan nie oor die manne van Ninevé dat God hulle sakkleding en vastery gesien het nie, maar: 'En God het hulle werke gesien en dat hulle hulle van hulle bose weë bekeer het"'.

$9 \quad$ Seltzer, $a w, 114$.

10 Elia en Jona word reeds baie nou aan mekaar verbind in die Mishnatraktaat Taanit 2:4, waăr dit gaan oor voorbeelde van gebedsverhoring.

11 G Friedlander, Pirke de-Rabbi Eliezer, New York 1981, 69. Die Joodse gebruik om alle onverklaarbare gebeure, soos die groot vis, die wonderboom, en dies meer te beskou as voorafbestemde skeppingswerke van God (vgl H Strack \& P Billerbeck, Das Evangelium nach Matthäus erläutert aus Talmud und Midrasch, München 1926, 645) mag dalk lig werp op die betekenis van die Pauliniese frase "voor die grondlegging van die wêreld".

12 Seltzer, $a w, 94$ - my vertaling.

13 Seltzer, tap.

14 Seltzer, $a w, 148$.

15 Vir 'n volledige oorsig oor dié tradisie, kyk Seltzer, aw, 320-334.

16 Friedlander, $a w, 70-72$; Duitse vertaling by Strack \& Billerbeck, tap.

17 Sou die "lastering teen die Heilige Gees" (Matt 12:31) miskien juis kon wees wanneer mense goddelike krag duiwelse krag noem en 'n Godsgesant 'n duiwelsgesant? Sou dié onvergeeflike sonde moontlik 'n messiaanse konteks hê?

18 R Pattai, The Messiah texts, New York 1979, 227-228.

19 Seltzer, $a w, 351 \mathrm{ev}, 380$.

20 Patai, $a w, 125-126$.

21 L Ginzberg, The Legends of the Jews 6 (transl. H. Szold), Philadelphia 1968, 351.

22 R Patai, $a w, 160-161$ : "And the Holy One, blessed be He, will whistle and gather all Israel and bring them to Jerusalem... And from heaven will descend built-up and embellished Jerusalem... And all nations will walk in the light... And Israel will dwell in security for two thousand years, and they will eat Behemoth and Leviathan and Ziz".

Dit is ook interessant om daarop te let dat Leviatan, gekonfronteer met Jona, 
verskrik wegvlug, terwyl die duiwels in die Nuwe Testament Jesus óok as die Messias erken en bang is vir Hom, wat hulle finale Uitwisser sal wees. Die latere teologiese bespiegeling oor wat Jesus gedurende die drie dae in die graf gedoen het (bv dat Hy na die doderyk gegaan het om vir die "geeste in die gevangenes" te preek) kon deels ook deur die Joodse tradisie oor Jona se voorlopige konfrontasie met Leviatan tydens sy verblyf in die vis geïnspireer gewees het. 